\title{
A case-control study of factors associated with SARS-CoV-2 infection among healthcare workers in Colombia
}

\author{
Merida Rodriguez-Lopez ${ }^{1 *}$ (D), Beatriz Parra², Enrique Vergara' ${ }^{1}$ Laura Rey ${ }^{1}$, Mercedes Salcedo², Gabriela Arturo ${ }^{3}$,
} Liliana Alarcon ${ }^{3}$, Jorge Holguin ${ }^{1,3}$ and Lyda Osorio²

\begin{abstract}
Background: Healthcare Workers (HCW) are repeatedly exposed to SARS-CoV-2 infection. The aim of this study was to identify factors associated with SARS-CoV-2 infection among HCW in one of the largest cities in Colombia.

Methods: We conducted a case-control study, where cases had a positive reverse transcription-polymerase chain reaction and controls had a negative result. Participants were randomly selected and interviewed by phone. Analyses were performed using logistic regression models.

Results: A total of 110 cases and 113 controls were included. Men (AdjOR 4.13 95\% Cl 1.70-10.05), Nurses (AdjOR 11.24 95\% Cl 1.05-119.63), not using a high-performance filtering mask (AdjOR 2.27 95\% Cl 1.02-5.05) and inadequate use of personal protective equipment (AdjOR $4.8295 \% \mathrm{Cl} 1.18-19.65$ ) were identified as risk factors. Conversely, graduate (AdjOR 0.06 95\% Cl 0.01-0.53) and postgraduate (AdjOR 0.05 95\% Cl 0.005-0.7) education, feeling scared or nervous (AdjOR 0.45 95\% Cl 0.22-0.91), not always wearing any gloves, caps and goggles/face shields (AdjOR 0.10 $95 \% \mathrm{Cl} 0.02-0.41$ ), and the use of high-performance filtering or a combination of fabric plus surgical mask (AdjOR 0.27 $95 \% \mathrm{Cl} 0.09-0.80$ ) outside the workplace were protective factors.

Conclusion: This study highlights the protection provided by high-performance filtering masks or double masking among HCW. Modifiable and non-modifiable factors and the difficulty of wearing other protective equipment needs to be considered in designing, implementing and monitoring COVID-19 biosafety protocols for HCW.
\end{abstract}

Keywords: COVID-19, SARS-CoV-2, Risk factors, Healthcare workers

\section{Introduction}

Over 55 millions of people were infected worldwide by the Severe Acute Respiratory Syndrome Coronavirus 2 (SARS-CoV-2) in 2020 [1]. In previous coronavirus pandemic outbreaks, SARS-CoV-1 in 2003 and the Middle East Respiratory Syndrome in 2012, between 10 and $20 \%$ of infected people were Healthcare Workers (HCW)

\footnotetext{
*Correspondence: merida.rdguez@gmail.com

1 Pontificia Universidad Javeriana Seccional Cali, Calle 18 No.118 - 250

Edificio Raúl Posada S.J. Tercer Piso, Cali, Colombia

Full list of author information is available at the end of the article
}

$[2,3]$. In the current pandemic, the prevalence among $\mathrm{HCW}$ varies between countries from 2 to $30 \%$ [4]. The Coronavirus Disease 2019 (COVID-19) caused by SARS$\mathrm{CoV}-2$, affects people's lives and threatens their biological $[5,6]$, physiological $[7,8]$, family and social health $[9$, 10]. HCW are repeatedly exposed to the virus leading to an increased risk of the disease [11] and sequelae [12] compared to the general population. Hence, COVID-19 could reduce the workforce availability to respond to this emergency.

The first case of SARS-CoV-2 in Colombia was reported in March 2020. Seven months later, the

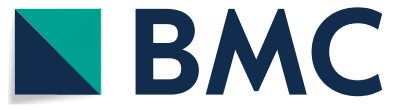

(0) The Author(s) 2021. Open Access This article is licensed under a Creative Commons Attribution 4.0 International License, which permits use, sharing, adaptation, distribution and reproduction in any medium or format, as long as you give appropriate credit to the original author(s) and the source, provide a link to the Creative Commons licence, and indicate if changes were made. The images or other third party material in this article are included in the article's Creative Commons licence, unless indicated otherwise in a credit line to the material. If material is not included in the article's Creative Commons licence and your intended use is not permitted by statutory regulation or exceeds the permitted use, you will need to obtain permission directly from the copyright holder. To view a copy of this licence, visit http://creativecommons.org/licenses/by/4.0/. The Creative Commons Public Domain Dedication waiver (http://creativeco mmons.org/publicdomain/zero/1.0/) applies to the data made available in this article, unless otherwise stated in a credit line to the data. 
Colombian National Institute of Health has informed over 16,500 infected $\mathrm{HCW}$, most of whom were associated to the workplace [13]. In a descriptive study of $\mathrm{HCW}$ in Cali, one of the largest cities in Colombia, 65\% of infections were related to the workplace and the most affected were women and nursing assistants [14]. To date, there is scarce evidence in Latin America, concerning risk factors for the infection particularly among $\mathrm{HCW}$, who are exposed to both, workplace and community transmission. Studies are mostly from Asia, Europe and North America [15-18]. They have focused on nurses and medical staff, and they have mainly evaluated the presence of symptoms and the exposures to occupational factors, including aerosol-generating procedures [15]. Cultural differences and availability of resources between countries and institutions, limit a direct extrapolation of previous findings. Less is known about the effect of factors related to potential community transmission or the risk among other hospital workers. Moreover, there is controversy abound the appropriate types of masks for $\mathrm{HCW}$ in community settings [19]. Therefore, the aim of this study was to determine the factors associated with SARS-CoV-2 infection among HCW in Cali, Colombia.

\section{Subjects and methods}

\section{Study design}

We conducted a case-control study in HCW who served in health care institutions in Cali, Colombia. Participants were identified by merging the database of positive reverse transcription-polymerase chain reaction (RT-PCR) results with the routine surveillance system of COVID-19 (event code 346) or acute respiratory infections (event codes 345 and 348), who were reported with or without symptoms (as part of cluster investigations), between June $10^{\text {th }}$ and July $25^{\text {th }}, 2020$. This time framework matches the first peak of the epidemic curve

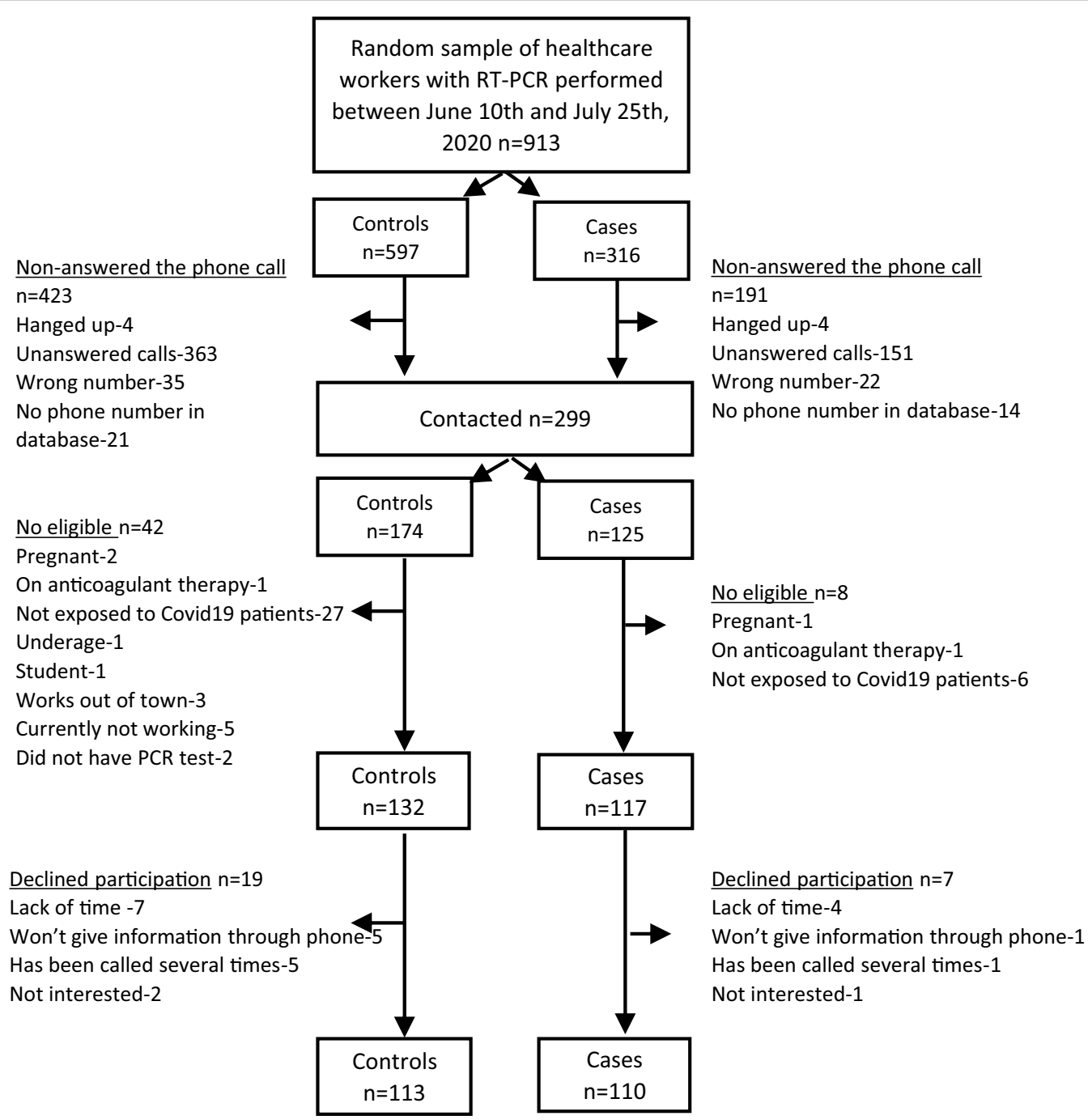

Fig. 1 Flowchart of the study participants 
in Cali [20]. Cases and controls were randomly (simple random sampling without replacement) selected from those identified as $\mathrm{HCW}$ with a positive and negative test, respectively. The outcome status was confirmed with the database of epidemiological investigation of COVID19 in health care facilities compiled by the local health authorities of Cali and during the telephone interview. This strategy ensures a representative sample of different health care institutions independently of size, patient type, care level, management or service provided. Sample size was estimated as 111 participants for each group with $80 \%$ power, $95 \%$ level of confidence, $18 \%$ of exposure among controls, Odds Ratio (OR) of 2.5, 1:1 allocation ratio, and $10 \%$ of withdrawal.

$\mathrm{HCW}$ were defined as those working in healthcare environments regardless of whether they were directly or indirectly involved in clinical activities such driving an ambulance or worked in a hospital or in homecare. Potential participants were contacted by phone and eligibility criteria were confirmed (18 years or older, not being pregnant or having a coagulopathy, and working in a health care institution that have the potential to assist COVID-19 patients, or being in contact before they had a RT-PCR test with infectious materials such as body fluids and contaminated surfaces and supplies). The study protocol was part of the public health research to face the pandemic and was revised by the Universidad Javeriana Cali Ethics Committee. Inform consent was obtained online for all participants.

\section{Data collection}

Data was collected by two trained researchers via telephone and using a structured questionnaire. The questionnaire included modifiable and non-modifiable factors: sociodemographic, clinical and lifestyle factors referred to six months before the test result, psychological factors referred to one month before the test. Occupational, exposure to COVID-19 cases, social behavior and personal protection equipment (PPE) factors referred to two weeks before the RT-PCR test. Feeling scared or nervous or having insomnia were evaluated by a five-point Likert scale, and further dichotomized as never or anytime. Height, weight, and compliance to recommended PPE use were self-reported. The exposure to a positive person was evaluated by the question: "To your knowledge, were you in contact with a person diagnosed with COVID-19, at least 2 weeks prior to the test?" A high-performance filtering mask was considered as the use of N95, P100 or M3. The frequency of use of each PPE at work were classified as always wearing them or not. Self-perception of the adequate use of PPE was evaluated as many times, sometimes or few times. The use of medicines for prophylaxis purposes included hydroxychloroquine and ivermectin. Vitamins, nutritional supplements, and hormonal contraceptives, usually taken for a long period were also included. Interviewers were blinded to the case status. At the end of each interview, blindness was broken to confirm the status of each participant as to prevent potential misclassification bias due to controls having a positive test after their report to the surveillance system.

\section{Statistical analysis}

Normality assumption was checked using Shapiro Wilk test. Then, study groups were described and compared using median (interquartile range) and relative frequencies for quantitative and qualitative variables, respectively. Body Mass Index (BMI) was estimated from self-reported weight and height and categorized as obese $\left(\geq 30 \mathrm{~kg} / \mathrm{m}^{2}\right)$, overweight $\left(25\right.$ to $\left.<30 \mathrm{~kg} / \mathrm{m}^{2}\right)$ and not overweight nor obese $\left(<25 \mathrm{~kg} / \mathrm{m}^{2}\right)$. Epidemiological weeks were calculated based on the date of the test result. To account for correlation among exposures in multiple analysis, new variables were defined. For example, the use of surgical caps, goggles/face shields, and gloves were grouped as single PPE. As HCW may have work in more than one hospital area, these were classified according to risk as "high-risk" if working in COVID-19-designated zones and any of emergency room, inpatient ward or intensive care unit (ICU), as "middle risk" if did not work in a COVID-19-designated zone but in emergency or ICU, and as "low risk" if did not work in COVID-19-designated zone nor emergency nor ICU.

Mann-Whitney $U$-test and Chi-Square or Fisher test were used for comparisons as appropriate. Multiple Logistic regression models were fitted using the backward strategy and the likelihood ratio test. A variable remained in the model when partial $\mathrm{F}$ had a $P \leq 0.10$, when confounding effect was observed, or by its clinical relevance on the outcome (i.e.; epidemiological weeks and hospital area). Model fit was evaluated by Hosmer and Lemeshow test. Calibration, specificity, and collinearity was also checked. The final model was selected considering the highest explicative ability measured by PseudoR ${ }^{2}$. Analyses were performed using Stata version 15 (StataCorp. LP, College Station,TX).

\section{Results}

The flow diagram of the study population is shown in Fig. 1. Among those contacted that met the eligibility criteria, $5 \%$ of cases and $14 \%$ of controls declined to participate, resulting in a final sample of 110 cases and 113 controls. RT-PCR was ordered because of symptoms in $59.2 \%$ of participants and the remaining $40.8 \%$ as part of contact tracing or institutional screening. At the time of the interview, all $\mathrm{HCW}$ reported to wear some type of 
Table 1 Association between sociodemographic, clinical, lifestyle and psychological characteristics with SARS-CoV-2 infection among HCW

\begin{tabular}{|c|c|c|c|c|}
\hline Characteristics & $\begin{array}{l}\text { Negative RT-PCR } \\
\mathrm{n}=113\end{array}$ & Positive RT-PCR $n=110$ & Unadjusted OR $(95 \% \mathrm{Cl})$ & $P$ value \\
\hline \multicolumn{5}{|l|}{ Sociodemographic } \\
\hline Age, years & $30(26-34)$ & $30(27-34)$ & $0.98(0.95-1.02)$ & 0.40 \\
\hline \multicolumn{5}{|l|}{ Gender, n (\%) } \\
\hline Female, not taking hormonal contraceptives & $82(72.57)$ & $57(51.82)$ & Ref. & \\
\hline Female, taking hormonal contraceptives & $11(9.73)$ & $16(14.55)$ & $2.09(0.90-4.84)$ & 0.08 \\
\hline Male & $20(17.70)$ & $37(33.64)$ & $2.66(1.40-5.04)$ & $<0.01$ \\
\hline \multicolumn{5}{|l|}{ Socioeconomic stratum, n (\%) } \\
\hline $\operatorname{Low}(1-2)$ & $37(32.74)$ & $31(28.18)$ & & \\
\hline Middle (3-4) & $56(49.56)$ & $68(61.82)$ & $1.44(0.80-2.63)$ & 0.22 \\
\hline $\operatorname{High}(\geq 5)$ & $20(17.70)$ & $11(10)$ & $0.65(0.27-1.57)$ & 0.35 \\
\hline \multicolumn{5}{|l|}{ Race, $n(\%)$} \\
\hline White & $37(32.74)$ & $31(28.18)$ & Ref. & \\
\hline Mestizo & $63(55.75)$ & $62(56.37)$ & $1.17(0.65-2.12)$ & 0.59 \\
\hline Afrocolombian & $13(11.50)$ & $17(15.45)$ & $1.56(0.66-3.71)$ & 0.31 \\
\hline \multicolumn{5}{|l|}{ Highest educational level, n (\%) } \\
\hline Non-college education & $50(44.25)$ & $62(56.36)$ & Ref. & \\
\hline College graduate & $40(35.39)$ & $36(32.73)$ & $0.72(0.40-1.30)$ & 0.28 \\
\hline Postgraduate education & $23(20.35)$ & $12(10.91)$ & $0.42(0.19-0.93)$ & 0.03 \\
\hline \multicolumn{5}{|l|}{ Marital status, n (\%) } \\
\hline Married or in common law & $41(36.28)$ & $45(40.91)$ & Ref. & \\
\hline Single or Divorced & $72(63.72)$ & $65(59.09)$ & $0.82(0.48-1.41)$ & 0.48 \\
\hline \multicolumn{5}{|l|}{ Number of members in household, $\mathrm{n}(\%)$} \\
\hline$\leq 1$ & $24(21.24)$ & $37(33.64)$ & Ref. & \\
\hline$>2$ & $89(78.76)$ & $73(66.36)$ & $0.53(0.29-0.97)$ & 0.04 \\
\hline Epidemiological weeks, weeks & $27(25-28)$ & $27(26-28)$ & $1.11(0.95-1.30)$ & 0.18 \\
\hline \multicolumn{5}{|l|}{ Clinical, Life Style and Psychological risk factors } \\
\hline \multicolumn{5}{|l|}{ Obesity, n (\%) } \\
\hline Not overweight nor obese & $53(47.75)$ & $44(40.37)$ & Ref. & \\
\hline Overweight & $41(36.94)$ & $49(44.95)$ & $1.44(0.81-2.56)$ & 0.22 \\
\hline Obese & $17(15.32)$ & $16(14.68)$ & $1.13(0.51-2.50)$ & 0.76 \\
\hline \multicolumn{5}{|l|}{ Chronic disease, n (\%) } \\
\hline No & $100(88.50)$ & $95(86.36)$ & Ref. & \\
\hline Yes (HBP, DM, Asthma Hypothyroidism) & $13(11.50)$ & $15(13.64)$ & $1.21(0.54-2.68)$ & 0.63 \\
\hline \multicolumn{5}{|l|}{ Medication intake, $n(\%)$} \\
\hline Vitamins or supplements (yes) & $20(26.55)$ & $20(18.88)$ & $0.61(0.32-1.16)$ & 0.14 \\
\hline Chloroquine or Ivermectin (yes) & $14(12.39)$ & $7(6.36)$ & $0.48(0.19-1.24)$ & 0.13 \\
\hline \multicolumn{5}{|l|}{ Smoking habit, n (\%) } \\
\hline No & $92(81.42)$ & $85(77.27)$ & Ref. & \\
\hline Former or current smoker & $21(18.58)$ & $25(22.73)$ & $1.28(0.67-2.47)$ & 0.44 \\
\hline \multicolumn{5}{|l|}{ Alcohol intake, n (\%) } \\
\hline Never & $32(28.32)$ & $44(40)$ & Ref. & \\
\hline Monthly intake & $71(62.83)$ & $57(51.82)$ & $0.58(0.33-1.04)$ & 0.07 \\
\hline Weekly intake & $10(8.85)$ & $9(8.18)$ & $0.65(0.24-1.79)$ & 0.41 \\
\hline \multicolumn{5}{|l|}{ Feeling scared or nervous, n (\%) } \\
\hline Never & $41(36.28)$ & $57(51.82)$ & Ref. & \\
\hline Anytime & $72(63.72)$ & $53(48.18)$ & $0.53(0.31-0.90)$ & 0.02 \\
\hline \multicolumn{5}{|l|}{ Insomnia, n (\%) } \\
\hline Never & $49(43.36)$ & $52(47.27)$ & Ref. & \\
\hline Anytime & $64(56.64)$ & $58(52.73)$ & $0.85(0.50-1.45)$ & 0.56 \\
\hline
\end{tabular}

HBP High Blood Pressure, DM Diabetes Mellitus 
Table 2 Association between occupational, exposure and social behavior factors and SARS-CoV-2 infection among HCW

\begin{tabular}{|c|c|c|c|c|}
\hline Characteristics & $\begin{array}{l}\text { Negative RT-PCR } \\
n=113\end{array}$ & $\begin{array}{l}\text { Positive RT-PCR } \\
n=110\end{array}$ & Unadjusted OR (95\% Cl) & $P$ value \\
\hline \multicolumn{5}{|l|}{ Occupation, n (\%) } \\
\hline Nursing Assistant & $31(27.43)$ & $38(34.55)$ & Ref. & \\
\hline Nurse & $18(15.93)$ & $19(17.27)$ & $0.86(0.39-1.91)$ & 0.71 \\
\hline Physician & $25(22.12)$ & $18(16.36)$ & $0.58(0.27-1.27)$ & 0.17 \\
\hline Other healthcare professionals ${ }^{\mathrm{a}}$ & $12(10.62)$ & $10(9.09)$ & $0.68(0.26-1.78)$ & 0.43 \\
\hline Technicians & $12(10.62)$ & $15(13.64)$ & $1.01(0.42-2.49)$ & 0.96 \\
\hline Administrative Staff & $15(13.27)$ & $10(9.09)$ & $0.54(0.21-1.37)$ & 0.19 \\
\hline \multicolumn{5}{|l|}{ Workplace risk area, n (\%) } \\
\hline Worked in a COVID-19 zone (yes) & $47(41.59)$ & $52(47.27)$ & $1.25(0.74-2.13)$ & 0.39 \\
\hline Worked in a high-risk area (yes) & $54(47.79)$ & $70(63.64)$ & $1.91(1.12-3.27)$ & 0.02 \\
\hline \multicolumn{5}{|l|}{ Night shifts, n (\%) } \\
\hline No & $61(53.98)$ & $42(38.18)$ & Ref. & \\
\hline Yes & $52(46.02)$ & $68(61.82)$ & $1.89(1.11-3.23)$ & 0.02 \\
\hline \multicolumn{5}{|c|}{ Face-to-face contact with a positive case, n (\%) } \\
\hline No contact & $29(25.66)$ & $29(26.36)$ & Ref. & \\
\hline Yes, family or work colleagues & $42(37.16)$ & $22(20)$ & $0.52(0.25-1.09)$ & 0.08 \\
\hline Yes, patients & $42(37.17)$ & $59(53.64)$ & $1.40(0.73-2.69)$ & 0.30 \\
\hline \multicolumn{5}{|l|}{ Shared spaces at work, n (\%) } \\
\hline Cafeteria (yes) & $42(37.17)$ & $38(34.55)$ & $0.89(0.52-1.54)$ & 0.68 \\
\hline Resting places (yes) & $14(12.39)$ & $22(20)$ & $1.77(0.85-3.66)$ & 0.13 \\
\hline \multicolumn{5}{|l|}{ Means of transportation to work, $\mathrm{n}(\%)$} \\
\hline None or private & $84(74.34)$ & $77(70)$ & Ref. & \\
\hline Taxi, Ridesharing, Public transportation & $29(25.66)$ & $33(30)$ & $1.24(0.69-2.23)$ & 0.47 \\
\hline \multicolumn{5}{|l|}{ Outings besides work, n (\%) } \\
\hline To the bank (yes) & $14(12.39)$ & $23(20.91)$ & $1.87(0.91-3.86)$ & 0.09 \\
\hline To the supermarket/store (yes) & $81(71.68)$ & $66(69.09)$ & $0.59(0.34-1.03)$ & 0.07 \\
\hline
\end{tabular}

${ }^{a}$ mainly dentists and physiotherapists

facemask in both the institutional and community settings. Oral contraceptives were the most common type of hormonal contraception (82\%). Differences between cases and control are shown in Tables 1, 2 and 3. Among females, the difference between cases and controls in the use of hormonal contraceptives was observed mainly in symptomatic women $(\mathrm{OR}=2.05$ 95\% CI 0.75-5.64).

Modifiable and non-modifiable risk factors remained in the multivariate model as shown in Table 4. The use of a high-performance mask or a combination of fabric and surgical mask outside the workplace showed a protective effect (AdjOR $=0.27$ 95\% CI 0.09-0.80). Not wearing any of surgical caps, face shields/goggles or gloves (AdjOR $=0.10$ 95\% CI 0.02-0.41) and feeling scared or nervous (AdjOR $=0.4595 \%$ CI 0.22-0.91) were also protective. On the contrary, not always wearing high-performance mask within the workplace (AdjOR $=2.27$ 95\% CI 1.02-5.05) and not using PPE properly (AdjOR $=4.8295 \%$ CI $1.18-19.65$ ) were positive associated with the infection. Male gender (AdjOR $=4.13$ 95\% CI 1.70-10.05) and being nurse AdjOR $=11.24$ 95\% CI 1.05-119.63) increased the risk, while college graduate $\mathrm{AdjOR}=0.0695 \% \mathrm{CI} 0.01-0.53)$ and postgraduate education (AdjOR $=0.0595 \%$ CI $0.005-0.47$ ) reduced the risk of a positive RT-PCR.

\section{Discussion}

This study identified modifiable and non-modifiable factors associated to a positive RT-PCR among HCW. Particularly, a greater protective effect of high-performance masks, or double masking outside the workplace was observed when compared to other types. Conversely, surgical caps, face shields/goggles and gloves were found to increase risk. Psychological factors that prevented being overconfident about SARS-CoV-2 transmission were protective. For non-modifiable factors, male gender increased the risk while higher level of education was protective. 
Table 3 Association between personal protection equipment at work and in the community and SARS-CoV-2 infection among HCW

\begin{tabular}{|c|c|c|c|c|}
\hline Characteristics & Negative RT-PCR $n=113$ & Positive RT-PCR $n=110$ & Unadjusted OR (95\% Cl) & $P$ value \\
\hline \multicolumn{5}{|c|}{ Use of High-performance filtering mask, n (\%) } \\
\hline Always & $51(45.13)$ & $47(42.73)$ & Ref. & \\
\hline Not always or another mask & $62(54.87)$ & $63(57.27)$ & $1.10(0.65-1.86)$ & 0.72 \\
\hline \multicolumn{5}{|l|}{ Use of Gloves, n (\%) } \\
\hline Always & $58(51.33)$ & $72(65.45)$ & & \\
\hline Not always & $55(48.67)$ & $38(34.55)$ & $0.56(0.32-0.95)$ & 0.03 \\
\hline \multicolumn{5}{|l|}{ Use of Face shield or goggles, $\mathrm{n}(\%)$} \\
\hline Always & $65(57.52)$ & $77(70)$ & & \\
\hline Not always & $48(42.48)$ & $33(30)$ & $0.58(0.33-1.01)$ & 0.05 \\
\hline \multicolumn{5}{|l|}{ Use of Surgical cap, n (\%) } \\
\hline Always & $52(46.02)$ & $73(66.36)$ & Ref. & \\
\hline Not always & $61(53.98)$ & $35(33.64)$ & $0.43(0.25-0.74)$ & $<0.01$ \\
\hline \multicolumn{5}{|l|}{ Used PPE properly, n (\%) } \\
\hline Many times & $108(95.58)$ & $97(88.18)$ & Ref. & \\
\hline Sometimes/few times & $5(4.42)$ & $13(11.82)$ & $2.89(1-8.42)$ & 0.05 \\
\hline \multicolumn{5}{|l|}{ Training PPE support, n (\%) } \\
\hline None & $20(17.70)$ & $9(8.18)$ & Ref. & \\
\hline$<2 \mathrm{~h}$ & $60(53.10)$ & $62(56.36)$ & $2.30(0.97-5.44)$ & 0.06 \\
\hline$\geq 2 \mathrm{~h}$ & $33(29.20)$ & $39(35.45)$ & $2.63(1.05-6.54)$ & 0.04 \\
\hline \multicolumn{5}{|l|}{ Type of facemask outside of work, n (\%) } \\
\hline Surgical mask & $69(61.06)$ & $79(71.82)$ & Ref. & \\
\hline $\begin{array}{l}\text { High-performance or fabric plus surgical } \\
\text { mask }\end{array}$ & $27(23.89)$ & $12(10.91)$ & $0.39(0.18-0.82)$ & 0.01 \\
\hline Only fabric mask & $17(15.04)$ & $19(17.27)$ & $0.98(0.47-2.02)$ & 0.95 \\
\hline
\end{tabular}

Concerning face-masks, those HCW always-wearing high-performance filtering masks had a better protection when compared to those wearing them occasionally or wearing other types of facemasks. This protective effect is controversial in the literature, with results suggesting greater [21], similar [22] or even lower [23] protection compared to surgical masks. Different types of masks, manufacturer standards, and the evaluation of potential confounders may explain discordances between studies. In addition, there is not a clear recommendation for the type of mask that HCW need to wear outside the workplace $[19,24]$. In line with previous studies [25, 26], our results suggest that fabric and surgical masks performed similarly, while wearing high-performance filtering masks or a combination of fabric plus surgical mask reduces the risk of infection compared to the use of surgical mask exclusively. Therefore, HCW could be advised to wear high-performance mask even when they are not directly taking care of COVID-19 patients, or in case of a shortage, low resource settings or high cost of highperformance masks, a combination of fabric plus surgical mask as an alternative.

Controversially, our study reported a greater risk among those who always wore face shields/goggles, gloves and surgical caps. In this regard, the evidence is limited [24] and the statistically significant protective effect disappears after covariates adjustment [27]. A false sense of safety resulting in self-contamination, sharing reusable PPE without appropriate disinfection protocols, or relaxing their use [28-30] could explain this result. In any case, emphasis needs to be given to the proper use of PPE during and after patient's care, as previously stated $[15,31-33]$.

Another modifiable psychological factor showing a protective effect was feeling scared or nervous. Despite the fact that we did not evaluate the source of stress, anxious individuals are less confident in their abilities to managing threated situations [34]. Therefore, they are more sensitive to feedback and to be hypervigilant in monitoring their surroundings and themselves which leads to strategic actions to avoid harm [35]. Whether this apparent protective effect will persist through the duration of the pandemic needs to be elucidated.

Non-modifiable risk factors included sex, education and occupation.Our results support a greater risk of having a positive RT-PCR among men. The testosterone suppression effect on the innate immune responses [36], the differential expression of ACE2 between males and 
Table 4 Multiple regression model of factors associated with SARS-CoV-2 infection in HCW. (Model also adjusted by epidemiological week and hospital area)

\section{Characteristics}

Gender

Female, not taking hormonal contraceptives

Female, taking hormonal contraceptives

Male

Highest educational level

Non-college education

College graduate

Postgraduate education

Number of members in the household

$\leq 1$

$>2$

Feeling scared or nervous

Never

Anytime

Alcohol intake

Never

Monthly intake

Weekly intake

Occupation

Nursing Assistant

Nurse

Physician

Other healthcare professionals ${ }^{\mathrm{a}}$

Technicians

Administrative Staff

Use of High-performance filtering mask

Always

Not always or another face mask

Always wear caps, face shield/goggles or gloves

Yes, all three of them

Yes, only two

Yes, only one

None

Used PPE properly

Yes

No

Type of facemask outside of work

Surgical mask

High-performance or fabric plus surgical mask

Only fabric mask

Training PPE support

None

$<2 \mathrm{~h}$

$\geq 2 \mathrm{~h}$
Adjusted OR $(95 \% \mathrm{CI})$

$P$ value

Ref.

$2.72(0.91-8.13)$

0.07

$4.13(1.70-10.05)$

$<0.01$

Ref.

$0.06(0.01-0.53)$

$0.05(0.005-0.47)$

Ref.

$0.47(0.21-1.04)$

0.06

Ref.

$0.45(0.22-0.91)$

Ref.

$0.50(0.23-1.07)$

0.08

$0.58(0.16-2.16)$

Ref.

$11.24(1.05-119.63) \quad 0.04$

$8.36(0.81-85.36) \quad 0.07$

$11.44(0.88-148.70) \quad 0.06$

$2.49(0.71-8.67) \quad 0.15$

$3.99(0.91-17.66) \quad 0.07$

Ref.

$2.27(1.02-5.05)$

0.04

Ref.

$0.69(0.25-1.96)$

0.49

$0.35(0.13-0.98)$

0.05

$0.10(0.02-0.41)$

$<0.01$

Ref.

4.82 (1.18-19.65)

Ref.

$0.27(0.09-0.80) \quad 0.02$

$0.84(0.32-2.20)$

Ref.

$2.73(0.83-8.92) \quad 0.10$

$3.42(0.97-12.01)$

${ }^{a}$ mainly dentists and physical therapists 
females [37], and a better compliance among women with biosafety measures [38] could explain the gender differences in COVID-19 susceptibility. Notably, we observed a differential but no significant risk among women according to the use of hormonal contraceptives, which requires further evaluation. The greater risk among lesseducated adults compared to university graduated is consistent with a previous report [39]. Our study reports a greater risk among nurses when compared to nursing assistants; however, the precision of this estimation was low. Despite these factors are not modifiable, some strategies focusing on high risk groups could be implemented to reduce their risk, e.g. special training and monitoring for men and less educated groups.

To prevent misclassification bias, interviewers were masked to the participant's case or control status. Although we did not quantify the possible effect of recall bias, phone questionnaires have been used in other pandemics [40] and are as valid as face-to-face interviews for collecting behavioural information [41, 42]. Moreover, we expect recall bias to be non-differential given that the time between the RT-PCR results and the interview were similar between groups. Self-report of anthropometric measures has been found to be accurate in terms of weight classification [43, 44]. The reasons for declining participation were similar between groups and were mainly related to availability (in terms of time), which made selection bias unlikely. Residual confounding could be present due to unmeasured variables such as quality of training, doffing practices, or the prevalence of the infection in the place of residence. In addition, residual confounding could be due to remaining differences in variables such as the type of hormonal contraceptives and the number of mask layers. Our results should not be extrapolated to the general population because health care workers are likely to behave differently regarding PPE use and risk of infection.

In conclusion, modifiable and non-modifiable factors were associated to SARS-CoV-2 infection among HCW, independent of the level of exposure. High-performance masks or double masking, adequate use of PPE and feeling scared or nervous were protective factors. In addition, gender, level of education along with occupational characteristics, were also associated with the risk of infection and need to be considered when planning public health and health care facilities prevention strategies.

\footnotetext{
Abbreviations

ACE: Angiotensin Converting Enzyme; Adj OR: Adjusted Odds Ratio; Cl: Confidence Interval; COVID-19: Coronavirus Infection Disease 2019; DM: Diabetes Mellitus; HCW: Health Care Worker; HBP: High Blood Pressure; PPE: Personal Protection Equipment; ICU: Intensive Care Unit; OR: Odds Ratio; RT-PCR: Reverse Transcription-Polymerase Chain Reaction; SARS-CoV-2: Severe Acute Respiratory Syndrome Coronavirus 2.
}

\section{Acknowledgements}

This work was supported by Pontificia Universidad Javeriana-Cali and Universidad del Valle. The content is solely the responsibility of the authors and does not necessarily represent the official view of Pontificia Universidad Javeriana or Universidad del Valle.

\section{Authors' contributions}

MR-L: Conception and design of the study, data collection, funding acquisition, statistical analysis, data interpretation, writing of the article and review and approval of the final version. LO: conception and design of the study, data collection, funding acquisition, statistical analysis, data interpretation, review and approval of the final version BP: Conception and designed of the study, funding acquisition, data collection and interpretation, review and approval of the final version. MS: Conception and designed of the study, data collection and interpretation, review and approval of the final version. EV \& LR: Data collection, review and approval of the final version. GA: Conception and designed of the study, data collection and interpretation, review and approval of the final version. LA \& JH: Data collection and interpretation, review and approval of the final version. All authors read and approved the final manuscript.

\section{Funding}

This work was supported by Pontificia Universidad Javeriana-Cali and Universidad del Valle.

\section{Availability of data and materials}

The datasets used and/or analysed during the current study are available from the corresponding author on reasonable request.

\section{Declarations}

Ethics approval and consent to participate

Informed consent was obtained from all participants. All methods were carried out in accordance with relevant guidelines and regulations. The study protocol was approved by the Universidad Javeriana Cali Ethics Committee.

\section{Consent for publication}

Not applicable.

\section{Competing interests}

The authors declare no competing interests.

\section{Author details}

${ }^{1}$ Pontificia Universidad Javeriana Seccional Cali, Calle 18 No.118 - 250 Edificio Raúl Posada S.J. Tercer Piso, Cali, Colombia. ${ }^{2}$ Universidad del Valle, Cali, Colombia. ${ }^{3}$ Secretaria de Salud Pública Municipal de Cali, Cali, Colombia.

Received: 21 April 2021 Accepted: 17 August 2021

Published online: 27 August 2021

\section{References}

1. 1Progressier. The Coronavirus App 2020. https://coronavirus.app/map. Accessed 1 Jan 2021.

2. World Health Organization. Summary of probable SARS cases with onset of illness from 1 November 2002 to 31 July 2003 2003. Available at: https:// www.who.int/csr/sars/country/table2004_04_21/en/ (accessed 1 January 2021).

3. World Health Organization. Epidemic and pandemic-prone diseases MERS situation update, January 2020 2019. https://applications.emro.who.int/docs/ EMCSR246E.pdf?ua=1. Accessed 1 Jan 2021.

4. Harrison D, Muradali K, El Sahly H, Bozkurt B, Jneid H. Impact of the SARSCoV-2 pandemic on health-care workers. Hosp Pract. 2020;48(4):161-4. https://doi.org/10.1080/21548331.2020.1771010.

5. Azer SA. COVID-19: pathophysiology, diagnosis, complications and investigational therapeutics. New Microbes New Infect. 2020;37: 100738. https://doi. org/10.1016/j.nmni.2020.100738.

6. Wu L, O'Kane AM, Peng H, Bi Y, Motriuk-Smith D, Ren J. SARS-CoV-2 and cardiovascular complications: from molecular mechanisms to pharmaceutical 
management. Biochem Pharmacol. 2020;178: 114114. https://doi.org/10. 1016/j.bcp.2020.114114.

7. Aksoy YE, Koçak V. Psychological effects of nurses and midwives due to COVID-19 outbreak: the case of Turkey. Arch Psychiatr Nurs. 2020;34(5):42733. https://doi.org/10.1016/j.apnu.2020.07.011.

8. Luo M, Guo L, Yu M, Jiang W, Wang H. The psychological and mental impact of coronavirus disease 2019 (COVID-19) on medical staff and general public - a systematic review and meta-analysis. Psychiatry Res. 2020;291: 113190. https://doi.org/10.1016/j.psychres.2020.113190.

9. Solis J, Franco-Paredes C, Henao-Martínez AF, Krsak M, Zimmer SM. Structural vulnerability in the U.S. revealed in three waves of COVID-19. Am JTrop Med Hyg. 2020;103(1):25-7. https://doi.org/10.4269/ajtmh.20-0391.

10. Fisayo T, Tsukagoshi S. Three waves of the COVID-19 pandemic. Postgrad Med J. 2020. https://doi.org/10.1136/postgradmedj-2020-138564.

11. Barrett ES, Horton DB, Roy J, Gennaro ML, Brooks A, Tischfield J, et al. Prevalence of SARS-CoV-2 infection in previously undiagnosed health care workers in New Jersey, at the onset of the U.S. COVID-19 pandemic. BMC Infect Dis. 2020;20(1):853. https://doi.org/10.1186/s12879-020-05587-2.

12. Ngai JC, Ko FW, Ng SS, To KW, Tong M, Hui DS. The long-term impact of severe acute respiratory syndrome on pulmonary function, exercise capacity and health status. Respirology. 2010;15(3):543-50. https://doi.org/10.1111/j. 1440-1843.2010.01720.x.

13. Instituto Nacional de Salud. COVID-19 en personal de salud en Colombia | Boletín No. 52 | 21-10-2020 2020. https://www.ins.gov.co/Noticias/Paginas/ coronavirus-personal-salud.aspx. Accessed 13 Jan 2021.

14. Torres M, Holguín J, Alarcón L, Arturo G, Luna A, Murillo S, et al. Análisis descriptivo de los casos positivos para COVID-19 del sector salud, Santiago de Cali-Colombia 2020. Gac Sanit. 2020;34:285-6.

15. Gómez-Ochoa SA, Franco OH, Rojas LZ, Raguindin PF, Roa-Díaz ZM, Wyssmann BM, et al. COVID-19 in healthcare workers: a living systematic review and meta-analysis of prevalence, risk factors, clinical characteristics, and outcomes. Am J Epidemiol. 2021;190(1):161-75. https://doi.org/10.1093/aje/ kwaa191.

16. Iversen K, Bundgaard H, Hasselbalch RB, Kristensen JH, Nielsen PB, Pries-Heje $\mathrm{M}$, et al. Risk of COVID-19 in health-care workers in Denmark: an observational cohort study. Lancet Infect Dis. 2020;20(12):1404-8. https://doi.org/10. 1016/S1473-3099(20)30589-2.

17. Liu T, Liang W, Zhong H, He J, Chen Z, He G, et al. Risk factors associated with COVID-19 infection: a retrospective cohort study based on contacts tracing. Emerg Microbes Infect. 2020;9(1):1546-53. https://doi.org/10.1080/22221751. 2020.1787799.

18. Ran L, Chen X, Wang Y, Wu W, Zhang L, Tan X. Risk factors of healthcare workers with corona virus disease 2019: a retrospective cohort study in a designated hospital of Wuhan in China. Clin Infect Dis. 2020;71(16):2218-21. https://doi.org/10.1093/cid/ciaa287.

19. Chou R, Dana T, Jungbauer R, Weeks C. Update alert 3: masks for prevention of respiratory virus infections, including SARS-CoV-2, in health care and community settings. Ann Intern Med. 2020. https://doi.org/10.7326/L20-1292.

20. COVID-19 en Colombia. https://www.ins.gov.co/Noticias/Paginas/coron avirus-filtro.aspx. Accessed 1 Jan 2021.

21. Chu DK, AkI EA, Duda S, Solo K, Yaacoub S, Schünemann HJ, et al. Physical distancing, face masks, and eye protection to prevent person-to-person transmission of SARS-CoV-2 and COVID-19: a systematic review and metaanalysis. Lancet. 2020;395(10242):1973-87. https://doi.org/10.1016/S01406736(20)31142-9.

22. Bartoszko JJ, Farooqi MAM, Alhazzani W, Loeb M. Medical masks vs N95 respirators for preventing COVID-19 in healthcare workers: a systematic review and meta-analysis of randomized trials. Influenza Other Respir Viruses. 2020;14(4):365-73. https://doi.org/10.1111/irv.12745.

23. Piapan L, De Michieli P, Ronchese F, Rui F, Mauro M, Peresson M, et al. COVID19 outbreak in healthcare workers in hospitals in Trieste. North-east Italy J Hosp Infect. 2020;106(3):626-8. https://doi.org/10.1016/j.jhin.2020.08.012.

24. Garcia LR, Jones AE, Anderson TN, Fisher CL, Seeley KML, Beeson EA, et al. Facial protection for healthcare workers during pandemics: a scoping review. BMJ Glob Health. 2020;5(5): e002553. https://doi.org/10.1136/ bmjgh-2020-002553.

25. Xiao J, Fang M, Chen Q, He B. SARS, MERS and COVID-19 among healthcare workers: a narrative review. J Infect Public Health. 2020;13(6):843-8. https:// doi.org/10.1016/j.jiph.2020.05.019.

26. Brooks J, Beezhold DH, Noti JD, et al. Maximizing fit for cloth and medical procedure masks to improve performance and reduce SARS-CoV-2 transmission and exposure 2021. MMWR. 2021. https://doi.org/10.15585/mmwr.mm700 $7 \mathrm{e} 1$.

27. Chou R, Dana T, Buckley DI, Selph S, Fu R, Totten AM. Update Alert 3: Epidemiology of and Risk Factors for Coronavirus Infection in Health Care Workers. Ann Intern Med. 2020;173(6):W123-4. https://doi.org/10.7326/L20-1005.

28. Reddy SC, Valderrama AL, Kuhar DT. Improving the use of personal protective equipment: applying lessons learned. Clin Infect Dis. 2019;69(Suppl 3):S165-70. https://doi.org/10.1093/cid/ciz619.

29. Zellmer C, Van Hoof S, Safdar N. Variation in health care worker removal of personal protective equipment. Am J Infect Control. 2015;43(7):750-1. https://doi.org/10.1016/.ajic.2015.02.005.

30. Katanami Y, Hayakawa K, Shimazaki T, Sugiki Y, Takaya S, Yamamoto K, et al. Adherence to contact precautions by different types of healthcare workers through video monitoring in a tertiary hospital. J Hosp Infect. 2018;100(1):705. https://doi.org/10.1016/j.jhin.2018.01.001.

31. Chatterjee P, Anand T, Singh KJ, Rasaily R, Singh R, Das S, et al. Healthcare workers \& SARS-CoV-2 infection in India: a case-control investigation in the time of COVID-19. Indian J Med Res. 2020;151(5):459-67. https://doi.org/10. 4103/ijmr.JJMR_2234_20.

32. Chou R, Dana T, Buckley DI, Selph S, Fu R, Totten AM. Epidemiology of and risk factors for coronavirus infection in health care workers: a living rapid review. Ann Intern Med. 2020;173(2):120-36. https://doi.org/10.7326/M20-1632.

33. Maclntyre CR, Wang $Q$, Cauchemez S, Seale H, Dwyer DE, Yang P, et al. A cluster randomized clinical trial comparing fit-tested and non-fit-tested N95 respirators to medical masks to prevent respiratory virus infection in health care workers. Influenza Other Respir Viruses. 2011;5(3):170-9. https://doi.org/ 10.1111/j.1750-2659.2011.00198.x.

34. Eysenck MW, Derakshan N. New perspectives in attentional control theory. Pers Individ Dif. 2011;50(7):955-60. https://doi.org/10.1016/.jpaid.2010.08.019.

35. Cheng BH, McCarthy JM. Understanding the dark and bright sides of anxiety: A theory of workplace anxiety. J Appl Psychol. 2018;103(5):537-60. https:// doi.org/10.1037/apl0000266.

36. Conti P, Younes A. Coronavirus COV-19/SARS-CoV-2 affects women less than men: clinical response to viral infection. J Biol Regul Homeost Agents. 2020;34(2):339-43. https://doi.org/10.23812/Editorial-Conti-3.

37. Komukai K, Mochizuki S, Yoshimura M. Gender and the renin-angiotensinaldosterone system. Fundam Clin Pharmacol. 2010;24(6):687-98. https://doi. org/10.1111/j.1472-8206.2010.00854.x.

38. Moran KR, Del Valle SY. A meta-analysis of the association between gender and protective behaviors in response to respiratory epidemics and pandemics. PLOS ONE. 2016;1 1(10): e0164541. https://doi.org/10.1371/journal.pone. 0164541.

39. Rezende LFM, Thome B, Schveitzer MC, Souza-Júnior PRB, Szwarcwald CL. Adults at high-risk of severe coronavirus disease-2019 (Covid-19) in Brazil. Rev Saude Publica. 2020;54:50. https://doi.org/10.11606/s1518-8787.2020054002 596.

40. Rubin GJ, Bakhshi S, Amlôt R, Fear N, Potts HWW, Michie S. The design of a survey questionnaire to measure perceptions and behaviour during an influenza pandemic: the Flu TElephone Survey Template (FluTEST). Southampton: NIHR Journals Library; 2014.

41. Smith A, Lyons A, Pitts M, Croy S, Ryall R, Garland S, et al. Assessing knowledge of human papillomavirus and collecting data on sexual behavior: computer assisted telephone versus face to face interviews. BMC Public Health. 2009. https://doi.org/10.1186/1471-2458-9-429.

42. Fenig S, Levav I, Kohn R, Yelin N. Telephone vs face-to-face interviewing in a community psychiatric survey. Am J Public Health. 1993;83(6):896-8. https:// doi.org/10.2105/ajph.83.6.896.

43. Bowring AL, Peeters A, Freak-Poli R, Lim MS, Gouillou M, Hellard M. Measuring the accuracy of self-reported height and weight in a community-based sample of young people. BMC Med Res Methodol. 2012;21(12):175. https:// doi.org/10.1186/1471-2288-12-175.

44. Wright FL, Green J, Reeves G, Beral V, Cairns BJ. Validity over time of selfreported anthropometric variables during follow-up of a large cohort of UK women. BMC Med Res Methodol. 2015. https://doi.org/10.1186/ s12874-015-0075-1.

\section{Publisher's Note}

Springer Nature remains neutral with regard to jurisdictional claims in published maps and institutional affiliations. 